\section{DETERMINING NEW EXPORT GOALS AND COMPETITIVE STRATEGIES FOR THE JEWELRY INDUSTRY IN EAST JAVA IN A GLOBAL VALUE CHAIN PERSPECTIVE}

\author{
Pranakusuma Sudhana ${ }^{1 *}$ \\ ${ }^{1}$ Dosen, Fakultas Ekonomi, Jurusan Manajemen, Universitas Widya Kartika
}

\begin{abstract}
Global Value Chain (GVC) is a relatively new concept where the process to produce goods or services occurs across countries. Previous research has concluded that integrating in GVC is important for a region to promote its economic growth. One indicator of a region's involvement in GVC is its export value at which in the Province of East Java, the jewelry industry (HS code 71) is the largest export contributor. This study aims to identify new export destinations based on trade data and to analyze internal factors of strength and weakness as well as external factors of opportunity and threat to formulate strategy to improve the competitiveness of jewelry industry with small, medium and large scale in East Java. In this research, the trade balance of jewelry industry between Indonesia and East Java and global importers was analyzed. The results show that some countries in Asia and Oceania, Europe and America are potential markets for the gold industry in East Java to increase the current value of exports. The geographical location of East Java which is close enough to the current export destination countries of jewelry products (Taiwan, Japan and Singapore) as well as potential destinations (India and China) is a competitive advantage. This research also identifies several strategies that can be done by the stakeholders in developing the jewelry industry in East Java.
\end{abstract}

Keywords: GVC, Jewelry Industry, Export, Strategy, Competitiveness

\section{ABSTRAK}

Global Value Chain (GVC) adalah sebuah konsep yang relatif baru dimana proses untuk menghasilkan barang atau jasa terjadi lintas negara. Penelitian sebelumnya menyimpulkan bahwa integrasi dalam GVC penting bagi suatu wilayah untuk mendorong pertumbuhan ekonominya. Salah satu indikator keterlibatan suatu daerah dalam GVC adalah nilai ekspornya dimana di Provinsi Jawa Timur industri perhiasan (kode HS 71) merupakan penyumbang ekspor terbesar. Penelitian ini bertujuan untuk mengidentifikasi negara tujuan ekspor baru berdasarkan data perdagangan dan menganalisis faktor internal kekuatan dan kelemahan serta faktor eksternal peluang dan ancaman untuk merumuskan strategi peningkatan daya saing industri perhiasan skala kecil, menengah dan besar di Jawa Timur. Dalam penelitian ini, neraca perdagangan industri perhiasan antara Indonesia dan Jawa Timur serta importir global dianalisis. Hasil penelitian menunjukkan bahwa beberapa negara di Asia dan Oceania, Eropa dan Amerika merupakan pasar potensial bagi industri emas di Jawa Timur untuk meningkatkan nilai ekspor saat ini. Letak geografis Jawa Timur yang cukup dekat dengan negara tujuan ekspor produk perhiasan saat ini (Taiwan, Jepang dan Singapura) serta destinasi potensial (India dan China) merupakan keunggulan kompetitif. Penelitian ini juga mengidentifikasi beberapa strategi yang dapat dilakukan oleh para pemangku kepentingan dalam mengembangkan industri perhiasan di Jawa Timur.

Kata Kunci: GVC, Industri Perhiasan, Ekspor, Strategi, Daya Saing

JEL : F15, F17, F18, L61

East Java Economic Journal, p-ISSN: 2597-8780, DOI: 10.53572/ejavec.v2i1.13, Open access undera Creative Commons Attribution- 4.0 Inter- 
Pendahuluan

Industri perhiasan (HS 71) merupakan kontributor ekspor terbesar di Provinsi Jawa Timur (Jatim). Data ekspor tahun 2016 dari Badan Pusat Statistik Provinsi Jawa Timur (BPS Jatim) menunjukkan bahwa hampir 22\% dari keseluruhan nilai ekspor Jatim atau sekitar 4,16 miliar dolar Amerika merupakan produk-produk perhiasan. Tabel 1 berikut merinci 10 komoditas ekspor Jatim di tahun 2016 yang tertinggi nilainya. Nampak pada tabel tersebut, total kontribusi kesepuluh komoditas tersebut mencapai hampir dua pertiga total nilai ekspor Jatim di tahun 2016. Dapat diamati pula bahwa terdapat perbedaan yang sangat signifikan dalam nilai ekspor antara peringkat pertama yaitu produk perhiasan dengan kontribusi lebih dari tiga kali lipat dibandingkan dengan peringkat kedua yaitu produk lemak dan minyak hewan/nabati, sebuah nilai yang hampir tidak mungkin tersaingi dalam waktu singkat.

Tabel : Komoditas Ekspor Jatim Tahun 2016 (dalam juta dolar Amerika)

\begin{tabular}{llll}
\hline Kode HS & Nama Komoditas & Nilai (FOB) & \% kontribusi \\
\hline 71 & perhiasan/permata & $4.161,76$ & 21,96 \\
\hline 15 & lemak dan minyak hewan/nabati & $1.282,43$ & 6,77 \\
\hline 44 & kayu, barang dari kayu & $1.148,30$ & 6,06 \\
\hline 03 & ikan dan udang & $1.059,86$ & 5,59 \\
\hline 27 & bahan bakar mineral & $1.009,53$ & 5,33 \\
\hline 74 & tembaga & 871,70 & 4,60 \\
\hline 29 & bahan kimia organik & 841,06 & 4,44 \\
\hline 48 & kertas/karton & 811,89 & 4,28 \\
\hline 38 & berbagai produk kimia & 578,32 & 3,05 \\
\hline 94 & perabot, penerangan rumah & 511,82 & 2,70 \\
\hline & lain-lain & $6.676,35$ & 35,23 \\
\hline Total & & & 100,00 \\
\hline
\end{tabular}

Sumber : Badan Pusat Statistik, 2017 (diolah)

Pada skala nasional, ternyata industri perhiasan Jatim juga merupakan kontributor ekspor yang terbesar. Sekitar lima tahun yang lalu, total nilai ekspor perhiasan nasional tercatat 2,59 milyar dolar Amerika dimana kontribusi ekspor perhiasan Jatim adalah 35,4\% dan merupakan yang terbesar (Martudji, 2011). Pemeringkatan tersebut berlanjut dimana data perdagangan tahun 2016 menunjukkan total nilai ekspor perhiasan nasional bertumbuh menjadi 5,34 milyar dolar Amerika dimana 64,42\% merupakan kontribusi ekspor perhiasan Jatim (Ibrahim, 2017).

Namun, pemberitaan terkini menunjukkan tanda-tanda penurunan nilai ekspor komoditas tersebut (Jawapos, 2017). Gambar 1 berikut menunjukkan perbandingan nilai ekspor perhiasan Jatim pada semester pertama (Januari-Juni) periode lima tahun terakhir. Nampak pada gambar tersebut, total nilai ekspor perhiasan di semester pertama 2017 hanya mencapai 1,60 juta dolar Amerika dimana mengalami penurunan sekitar $47 \%$ bila dibandingkan dengan periode yang sama tahun sebelumnya yaitu 3,01 juta dolar Amerika (Berita Resmi Statistik BPS Jatim Juli 2017). Hal tersebut cukup mengkhawatirkan karena industri perhiasan berkontribusi signifikan terhadap perekonomian nasional dengan mempunyai tiga keunggulan yaitu padat karya, berorientasi ekspor dan berdaya saing kuat (Okezone, 2017). 


\section{Gambar 1: Perbandingan Nilai Ekspor Perhiasan Jatim (Semester Pertama/Januari-Juni) Periode Lima Tahun Terakhir}

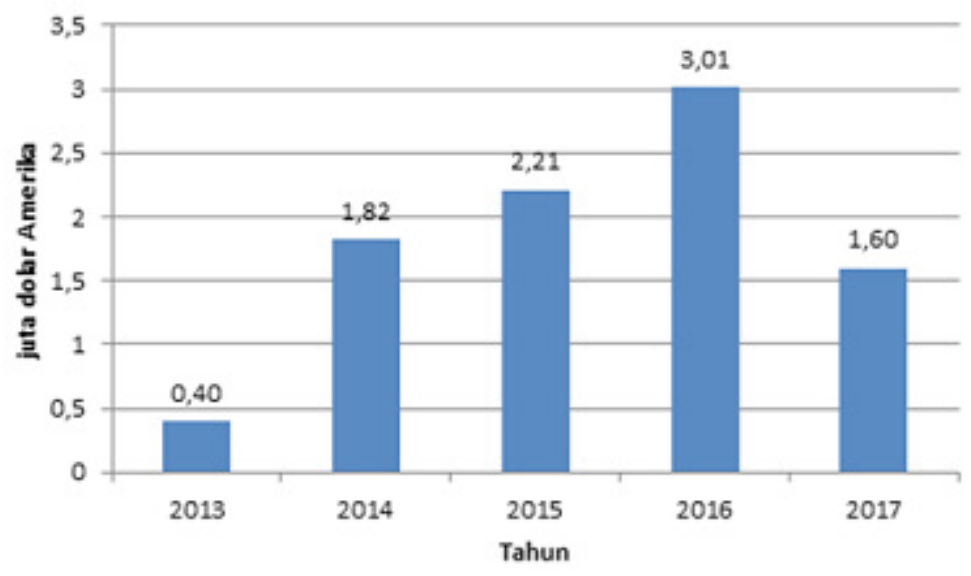

Sumber : BPS Jatim, diolah

Menurut Backer dan Miroudot (2013), nilai ekspor merupakan indikator keterlibatan suatu wilayah dalam perdagangan global yang diterminologikan sebagai Global Value Chain atau disingkat GVC. Keterlibatan suatu wilayah dalam GVC dapat mendorong pembangunan ekonomi wilayah tersebut karena terdapatnya potensi pendapatan, akses pasar, pengetahuan dan transfer teknologi (Serbanel, 2015). Berdasarkan kedua pendapat tersebut, dapat disimpulkan bahwa penurunan nilai ekspor akan menghambat pembangunan ekonomi suatu wilayah. Fenomena tersebut mendasari pentingnya dilakukan penelitian terhadap industri perhiasan di Jatim dalam perspektif GVC sehingga dapat kembali menjadi primadona ekspor.

Penelitian ini mempunyai dua tujuan yaitu untuk mengidentifikasi tujuan tujuan ekspor baru dan untuk memformulasikan strategi guna meningkatkan daya saing industri perhiasan baik dengan skala kecil, menengah maupun besar di Jawa Timur.

\section{Tinjauan Pustaka Industri Perhiasan}

Perhiasan merupakan komoditas yang sangat digemari masyarakat karena bentuknya yang relatif kecil namun bernilai tinggi (Dewi, 2010). Dalam studi yang sama, disebutkan pula bahwa perhiasan dari logam mulia mempunyai nilai ekonomis tinggi karena harganya yang terus meningkat, bentuknya relatif tidak berubah atau mengalami kerusakan sepanjang waktu (abadi) dan terdapatnya dampak psikologis misalnya sebagai simbol kesuksesan, kekuatan dan kemewahan pada beberapa budaya.

Selain sebagai produk yang superior, perhiasan sebagai industri juga mempunyai beberapa keunggulan. Padat modal dan padat karya merupakan yang pertama dimana industri tersebut mampu menyerap ribuan orang tenaga kerja dan mampu bertahan di tengah iklim perdagangan global yang tidak menentu (Ibrahim, 2017). Berdasarkan data tahun 2015, jumlah unit industri perhiasan dan aksesoris nasional mencapai 36.636 perusahaan dimana menyerap tenaga kerja sebanyak 43.348 orang. Sementara di Provinsi Jawa Timur, jumlah unit industri perhiasan saat ini sebanyak 26 industri berskala besar dan menengah, serta sekitar 1.854 industri berskala kecil yang tersebar di berbagai sentra industri di kota besar maupun kabupaten seperti Surabaya, Gresik, Lamongan, Pasuruan, Lumajang dan Pacitan (Okezone, 2017). Industri tersebut juga merupakan industri non-migas andalan Jatim karena industri berupa batubara dan minyak sudah tidak bisa diharapkan. 


\section{Global Value Chain (GVC)}

Cattaneo et al. (2013) menerangkan bahwa sejak dicetuskan pertama kali oleh Porter (1985), value chain atau rantai pasok merupakan cara untuk menganalisis kegiatan perdagangan berbagai organisasi dengan berbagai aktivitasnya dalam menghasilkan barang atau jasa, mulai dari ide atau gagasan, perencanaan, produksi, pemasaran, distribusi sampai pada penggunaan akhir dan seterusnya. Lebih lanjut, disebutkan juga bahwa berbagai aktivitas tersebut dapat dilakukan oleh satu, beberapa maupun banyak organisasi. Karena berbagai tuntutan dalam berkompetisi, di antaranya biaya produksi yang rendah, kondisi sosial dan lingkungan yang harus mendukung, sumber daya yang terbatas serta kedekatan pada konsumen akhir, maka proses produksi barang atau jasa dapat terjadi secara lintas negara atau terjadi secara global dan dikenal dengan GVC.

\section{GVC dari Industri Perhiasan}

DaSilva-Glasgow (2013) menjelaskan struktur rantai pasok (supply chain) dari perhiasan dalam hal ini dari bahan emas seperti yang tampak pada Gambar 2. Secara sederhana terdapat beberapa tahap pada rantai pasok tersebut yaitu: penelitian, penambangan emas, pemurnian emas dan perdagangannya, desain dan produksi perhiasan, pemasaran dan distribusi dan pendaur ulangan perhiasan.

Menurut data dari BPS, yang diekspor oleh Provinsi Jatim adalah produk produk perhiasan dengan klasifikasi HS 71 dimana berdasarkan www.foreign trade.com di dalamnya termasuk natural, cultured pearls; precious, semi-precious stones; precious metals, metals clad with precious metal, and articles thereof; imitation jewellery; coin. Apabila disepadankan dengan Rantai Pasok Industri Perhiasan Emas pada Gambar 2 di atas, maka posisi ekspor produk-produk perhiasan Jatim adalah pada tahap keempat (produksi perhiasan) dan tahap kelima (pemasaran dan distribusi). Dengan kata lain, posisi Jatim adalah pada intermediate dan final goods industry. Menurut DaSilva-Glasgow (2013) posisi yang demikian seharusnya sudah mampu memberikan nilai tambah yang jauh lebih besar daripada tahapan penambangan dan pemurnian emas (raw materials).

\section{Gambar 2: Rantai Pasok Industri Perhiasan Emas}

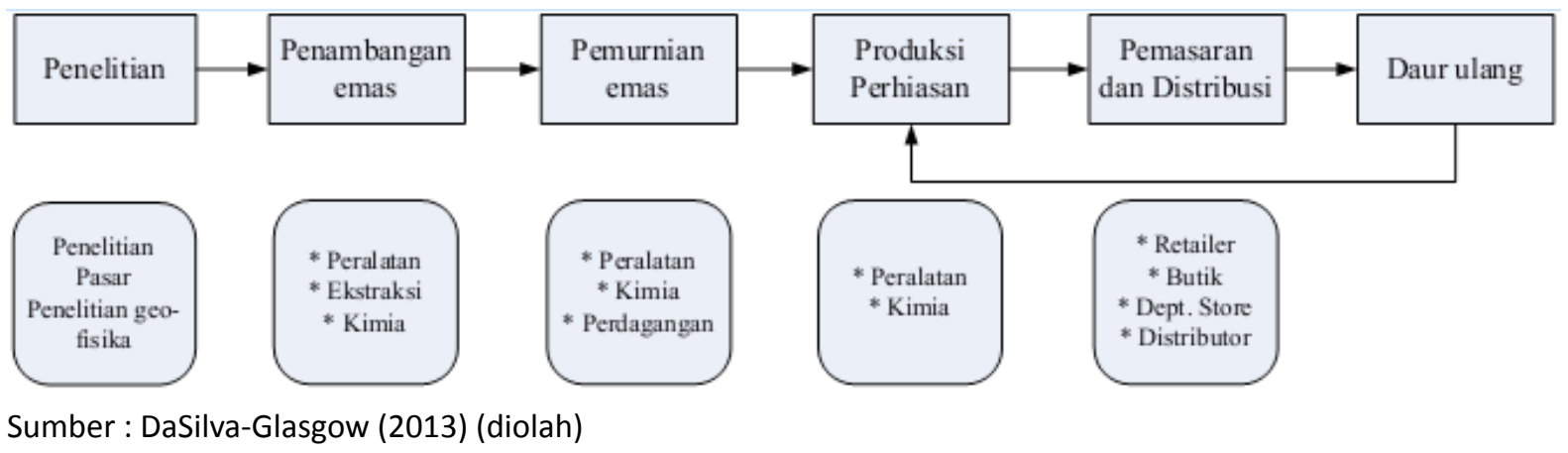

\section{Data dan Metodologi}

Sesuai dengan tujuan penelitian ini, pada bagian pertama, tujuan-tujuan ekspor baru diidentifikasi dengan mengolah data perdagangan berupa data sekunder dari BPS Jatim dan dari United Nations Comtrade (UN Comtrade). Sementara pada bagian kedua, formulasi strategi untuk meningkatkan daya saing industri perhiasan baik dengan skala kecil, menengah maupun besar di Jatim dilakukan dengan menganalisis faktor-faktor internal yaitu kekuatan (strength) dan kelemahan (weakness) serta faktor-faktor eksternal yaitu kesempatan (oppor- 
tunity) maupun ancaman (threat) atau lebih dikenal dengan analisis SWOT.

\section{Analisis Data Perdagangan}

Penelitian ini mula-mula meninjau data statistik perdagangan dari BPS yang seharusnya telah mempunyai validitas yang baik. Hal tersebut sejalan dengan gagasan penggunaan data yang bersumber dari BPS untuk perencanaan program program pembangunan nasional mulai tahun 2017 (mediaindonesia, 2016). Karena penelitian ini berfokus di Jawa Timur, maka dipakai data dari BPS Jatim yang terdiri dari "Statistik Ekspor Provinsi Jawa Timur" dan "Berita Resmi Statistik". Publikasi pertama merupakan upaya BPS Jatim untuk memberikan gambaran mengenai perkembangan ekonomi khususnya dari sisi ekspor. Data yang terdapat pada publikasi tersebut di antaranya ekspor menurut golongan barang (berdasarkan klasifikasi HS), negara tujuan utama dan kelompok barang utama. Pada penelitian ini, digunakan klasifikasi HS 2 digit atau HS2. Nilai barang yang dicatat adalah Free On Board (FOB) dalam dolar Amerika. Sedangkan publikasi kedua merupakan ringkasan perkembangan ekspor dan impor bulanan yang terjadi di Jatim dengan isi yang kurang lebih sama dengan publikasi pertama.

Selanjutnya, penelitian ini meninjau data statistik perdagangan dari United Nations Comtrade (UN Comtrade) yaitu nama untuk Database Statistik Perdagangan Internasional Perserikatan Bangsa-Bangsa atau United Nations International Trade Statistics Database. Lebih dari 170 negara dan wilayah menyediakan data perdagangan tahunan internasionalnya kepada United Nations Statistics Division (UNSD) dimana terdapat beberapa detail diantaranya mengenai jenis komoditas, nilai perdagangan serta negara-negara yang menjadi mitra mereka. Semua nilai perdagangan dikonversikan ke dalam dolar Amerika, sementara kuantitas dikonversikan ke dalam satuan metric. Komoditas perdagangan diklasifikasikan menurut Standard International Trade Classification (SITC), Harmonized System (HS) serta Broad Economic Categories (BEC). UN Comtrade adalah penyimpanan data perdagangan internasional terbesar dengan jumlah lebih 3 miliar data yang terkumpul sejak tahun 1962 dan tersedia untuk umum di internet. Salah satu metode untuk menggunakan UN Comtrade adalah dengan web interface dengan mengunjungi alamat web https://comtrade.un.org/data. Pada website tersebut dapat diamati pula beberapa input untuk mendapatkan data ekspor produk perhiasan Indonesia ke seluruh penjuru dunia di tahun 2016.

Identifikasi tujuan-tujuan ekspor baru dilakukan dengan menganalisis posisi neraca perdagangan industri perhiasan Indonesia dan Jawa Timur terhadap negara negara importir produk-produk tersebut di dunia serta kontribusi masing-masing negara importir (dalam persen) pada perdagangan global. Negara-negara dengan nilai impor yang besar namun belum menjadi tujuan ekspor inilah yang akan berpotensi menjadi tujuan-tujuan ekspor baru.

\section{Analisis SWOT}

Rangkuti (2004) dalam Nisak (2013) menyebutkan bahwa analisis SWOT digunakan untuk merumuskan strategi dengan memaksimalkan kekuatan (strength) dan kesempatan (opportunity) serta meminimalkan kelemahan (weakness) dan ancaman (threat). Masing-masing berturut-turut merupakan faktor internal dan eksternal. Matriks SWOT merupakan metode untuk menyusun faktor-faktor strategis tersebut seperti tampak pada Gambar 4 di bawah ini. Daft (2010) dalam artikel yang sama menyebutkan bahwa informasi mengenai faktor-faktor internal dan eksternal dapat diperoleh dari banyak sumber termasuk kliping surat kabar, riset di internet dan analisis tren-tren domestik maupun global yang relevan. 


\section{Gambar 3: Matriks SWOT}

\begin{tabular}{|l|l|l|}
\multicolumn{1}{c|}{} & $\begin{array}{l}\text { Strength (S) } \\
\text { tentukan 5-10 faktor kekuatan } \\
\text { internal }\end{array}$ & $\begin{array}{l}\text { Weakness (W) } \\
\text { tentukan 5-10 faktor kelemahan } \\
\text { internal }\end{array}$ \\
\hline $\begin{array}{l}\text { Opportunities (O) } \\
\text { tentukan 5-10 faktor } \\
\text { peluang eksternal }\end{array}$ & $\begin{array}{l}\text { Strategi S-O } \\
\text { strategi menggunakan kekuatan } \\
\text { untuk memanfaatkan peluang }\end{array}$ & $\begin{array}{l}\text { Strategi W-O } \\
\text { strategi meminimalkan kelemahan } \\
\text { untuk memanfaatkan peluang }\end{array}$ \\
\hline $\begin{array}{l}\text { Threaths (T) } \\
\text { tentukan 5-10 faktor } \\
\text { ancaman eksternal }\end{array}$ & $\begin{array}{l}\text { Strategi S-T } \\
\text { strategi menggunakan kekuatan } \\
\text { untuk mengatasi ancaman }\end{array}$ & $\begin{array}{l}\text { Strategi W-T } \\
\text { strategi meminimalkan kelemahan } \\
\text { untuk menghindari ancaman }\end{array}$ \\
\hline
\end{tabular}

Sumber : Nisak (2013)

\section{Hasil dan Analisa \\ Tujuan-Tujuan Ekspor Baru}

Tabel 2 berikut ini menyajikan neraca perdagangan komoditas perhiasan (HS 71) antara Indonesia dengan 20 besar importir produk-produk perhiasan di dunia (berurut dari importir yang terbesar) berdasarkan data UN Comtrade tahun 2016. Perlu dicatat bahwa nilai impor negara-negara tersebut mencapai hampir $97 \%$ dari keseluruhan nilai impor komoditas tersebut yang terjadi di seluruh dunia pada tahun 2016.

Tabel 2. Neraca Perdagangan Komoditas Perhiasan (kode HS 71) Tahun 2016

\begin{tabular}{|c|c|c|c|c|}
\hline Nama Negara & $\begin{array}{l}\text { Nilai Impor } \\
\text { (juta USD) }\end{array}$ & $\begin{array}{l}\text { Nilai Ekspor } \\
\text { Indonesia ke } \\
\text { negara ini } \\
\text { (juta USD) }\end{array}$ & $\begin{array}{l}\text { \% Kontribusi } \\
\text { Indonesia } \\
\text { dalam impor } \\
\text { negara ini }\end{array}$ & $\begin{array}{l}\text { Nilai Ekspor Jawa } \\
\text { Timur ke negara ini } \\
\text { (juta USD) }\end{array}$ \\
\hline Swiss & $99.675,03$ & $2.096,64$ & $2,10 \%$ & $1.965,02$ \\
\hline China & $79.327,27$ & 5,06 & $0,01 \%$ & 0,01 \\
\hline Inggris & $70.861,30$ & 45,28 & $0,06 \%$ & - \\
\hline Hong Kong & $67.220,84$ & 641,82 & $0,95 \%$ & - \\
\hline Amerika Serikat & $65.347,11$ & 107,77 & $0,16 \%$ & 58,75 \\
\hline Uni Emirat Arab & $52.896,62$ & 226,31 & $0,43 \%$ & - \\
\hline India & $48.129,74$ & 14,51 & $0,03 \%$ & 0,02 \\
\hline Belgia & $17.517,88$ & 0,41 & $0,00 \%$ & - \\
\hline Jerman & $15.364,03$ & 6,18 & $0,04 \%$ & - \\
\hline Singapura & $11.383,76$ & $2.154,44$ & $18,93 \%$ & 696,23 \\
\hline Kanada & $10.501,70$ & 0,82 & $0,00 \%$ & - \\
\hline Jepang & $9.991,83$ & 736,33 & $7,37 \%$ & 718,51 \\
\hline Italia & $9.606,50$ & 8,52 & $0,09 \%$ & - \\
\hline Australia & $7.603,95$ & 51,27 & $0,67 \%$ & - \\
\hline Israel & $7,495.56$ & 0,00 & $0,00 \%$ & - \\
\hline Turki & $7,204.35$ & 1,57 & $0,02 \%$ & - \\
\hline Prancis & $7,137.57$ & 1,30 & $0,02 \%$ & - \\
\hline Malaysia & $3,473.38$ & 0,06 & $0,00 \%$ & 0,01 \\
\hline Korea Selatan & $3.096,55$ & 3,42 & $0,11 \%$ & 0,0045 \\
\hline
\end{tabular}




\begin{tabular}{lllll}
\hline Nama Negara & $\begin{array}{l}\text { Nilai Impor } \\
\text { (juta USD) }\end{array}$ & $\begin{array}{l}\text { Nilai Ekspor } \\
\text { Indonesia ke } \\
\text { negara ini } \\
\text { (juta USD) }\end{array}$ & $\begin{array}{l}\text { \% Kontribusi } \\
\text { Indonesia } \\
\text { dalam impor } \\
\text { negara ini }\end{array}$ & $\begin{array}{l}\text { Nilai Ekspor Jawa } \\
\text { Timur ke negara ini } \\
\text { (juta USD) }\end{array}$ \\
\hline Spanyol & $1.850,08$ & 0,68 & $0,04 \%$ & - \\
\hline Negara lain & $18.512,80$ & & & \\
\hline Total & $614.197,93$ & &
\end{tabular}

Berdasarkan tabel di atas, dapat dianalisis beberapa hal. Pertama, kontribusi ekspor Indonesia terhadap impor negara-negara tersebut sangatlah kecil sehingga masih terdapat ruang untuk bertumbuh yang sangat besar. Hanya ke Swiss dan Singapura dimana ekspor Indonesia tampak signifikan dimana keduanya juga merupakan tujuan utama ekspor perhiasan Jatim. Sementara untuk negara-negara lainnya, ekspor Indonesia bahkan belum mencapai satu digit (di bawah 1\%).

Kedua, beberapa negara pengimpor terbesar produk-produk perhiasan berada di Asia, benua yang sama dengan Jatim. Negara-negara tersebut adalah China, Hong Kong, Uni Emirat Arab, India, Singapura, Jepang, Malaysia dan Korea Selatan. Salah satu topik diskusi pada World Economic Forum tahun 2016 yang berkaitan dengan GVC adalah meningkatnya pemanasan global yang salah satunya disebabkan oleh transportasi yang dibutuhkan pada proses produksi lintas negara. Karena fenomena pemanasan global membutuhkan partisipasi semua negara sebagai suatu keharusan untuk mengatasinya, muncul kecenderungan bahwa pengadaan barang di negara negara akan mendekati sumber produksinya. Untuk hal ini, industri perhiasan Jatim sangatlah diuntungkan karena posisinya yang strategis dimana dekat dengan negara negara importir tersebut yang total nilai impornya mencapai sekitar $45 \%$ dari total nilai impor produk perhiasan dunia tahun 2016.

Ketiga, khusus untuk India dan China (termasuk Hong Kong), World Gold Council (2015) telah mengidentifikasi keduanya sebagai destinasi ekspor perhiasan dunia yang sangat potensial. India mempunyai tradisi dalam mengkonsumsi dan memproduksi perhiasan. Masyarakatnya memiliki karakteristik yang menyebabkan permintaan akan perhiasan khususnya dari emas selalu meningkat yaitu suka membeli perhiasan untuk dikenakan pada acara-acara khusus, sering menjadikan perhiasan sebagai hadiah, menggunakan perhiasan sebagai media untuk menyimpan kekayaan dan perhiasan dibeli oleh berbagai kalangan baik kaya maupun tidak. Sebagai salah satu pasar perhiasan terbesar di dunia, India mengalami defisit perdagangan yang sangat besar. Ekspornya hanya memenuhi sekitar 8\% dari kebutuhan pasar global sementara impornya merupakan $20 \%-25 \%$ permintaan pasar global. Menurut laporan penelitian dari World Gold Council (2015), hal tersebut disebabkan adanya ketidakpercayaan baik pasar lokal maupun internasional terhadap kemurnian emas yang diproduksi oleh produsen-produsen dari India. Banyak ditemukan kecurangan yang dilakukan oleh mereka yang utamanya industri kecil menengah (IKM) dimana perhiasan dijual dengan harga melebihi kadar emas yang terkandung atau dikenal sebagai under-carated. Hal tersebut harus dilihat sebagai sebuah kesempatan bagi industri perhiasan Jatim untuk masuk ke pasar India serta bersaing dalam pemenuhan permintaan pasar global. Sejalan dengan hal tersebut, Gubernur Jatim, Soekarwo berpesan kepada industri perhiasan Jatim untuk selalu memperhatikan kejujuran sehingga tidak mengalami permasalahan yang sama (republika, 2015). Tidak berbeda jauh dengan India, emas merupakan tradisi di China. Pada zaman dahulu, emas dipakai untuk membuat stempel kerajaan penanda kekuasaan demikian juga para bangsawan mengenakan 
berbagai perhiasan untuk menunjukkan status dan kekayaan yang mereka miliki. Pada zaman modern ini, perhiasan khususnya dari emas masih mendominasi permintaan pasar lokal karena dipandang sebagai perlambang kemakmuran. Meskipun demikian, permintaan akan perhiasan dari emas semakin mengalami penurunan jumlahnya seiring dengan pergeseran selera konsumen kepada perhiasan dari platina dan berlian sebagai lambang eksklusivitas dan individualitas generasi milenial di sana. Fenomena pergeseran selera tradisional menuju pada sesuatu yang lebih modern tidak hanya terjadi pada produk-produk perhiasan saja namun juga pada sektor lain seperti makanan dan minuman dimana warung teh dan kopi semakin ditinggalkan dan generasi milenial lebih senang berada di Starbucks. Hal tersebut juga harus dilihat sebagai sebuah kesempatan bagi industri perhiasan Jatim untuk masuk ke pasar China dengan menjadi lebih kreatif dalam memproduksi perhiasan berbahan platina dan berlian.

Keempat, meskipun sebagian besar produk perhiasan yang dijual berasal dari Jatim (republika, 2015), pemberitaan terkini mengungkap bahwa Uni Emirat Arab saat ini bukan lagi merupakan pasar perhiasan yang baik. Terjadi penurunan penjualan retail yang cukup signifikan di tahun 2016. Terdapat beberapa faktor penyebab terjadinya hal tersebut yaitu tetap tingginya harga emas, menurunnya jumlah turis yang berkunjung serta pemberlakuan pajak terhadap impor produk perhiasan akhir-akhir ini (gulfnews, 2017). Industri perhiasan Jatim dapat mengantisipasinya dengan mencari pasar-pasar lain di sekitarnya yang masih prospektif misalnya Arab Saudi dan Turki.

Kelima, beberapa negara di Eropa merupakan pasar produk perhiasan yang prospektif, di antaranya Swiss, Inggris, Belgia dan Jerman. Meskipun Eropa terletak cukup jauh dari Jatim sehingga diperlukan usaha transportasi yang cukup signifikan, namun negara-negara tersebut telah menjalin hubungan perdagangan yang cukup lama dan baik dengan Jatim. Bahkan sejak tahun 2016, Inggris mempunyai perwakilan dagangnya di Surabaya (kominfo, 2016). Untuk lebih meningkatkan ekspor ke Eropa, industri perhiasan Jatim dapat memanfaatkan berbagai dukungan dan jaringan yang telah ada.

Berdasarkan analisis sebelumnya, maka dapat diidentifikasi tujuan-tujuan ekspor untuk produk perhiasan Jatim seperti nampak pada Tabel 3 berikut. Kolom "Tujuan ekspor saat ini" merinci negara-negara yang sudah menjadi mitra dagang dimana nilai ekspor dapat ditingkatkan dengan mengacu pada besaran nilai impor negara-negara tersebut. Kolom "Tujuan ekspor baru" merinci negara-negara yang berpotensi menjadi mitra dagang dengan mengacu besaran nilai impornya dan belum adanya catatan perdagangan komoditas perhiasan antara negara-negara tersebut dengan Jatim.

Tabel 3: Tujuan Ekspor Komoditas Perhiasan Jatim (HS 71)

\begin{tabular}{lll}
\hline Benua & Tujuan ekspor saat ini & Tujuan ekspor baru \\
\hline $\begin{array}{l}\text { Asia dan } \\
\text { Oceania }\end{array}$ & $\begin{array}{l}\text { China, India, Singapura, Jepang, } \\
\text { Malaysia, Korea Selatan }\end{array}$ & Israel, Turki, Australia \\
\hline Eropa & Swiss & $\begin{array}{l}\text { Inggris, Belgia, Jerman, Italia, Prancis, } \\
\text { Spanyol }\end{array}$ \\
\hline Amerika & Amerika Serikat & Kanada \\
\hline
\end{tabular}

\section{Strategi Peningkatan Daya Saing}

Berikut ini adalah hasil identifikasi faktor-faktor internal dan faktor-faktor eksternal industri perhiasan Jatim yang diperoleh dari berbagai sumber. 
a. Kekuatan (strength)

- Pasar global sangat menyukai produk emas dari Indonesia karena memiliki desain yang selalu berganti setiap bulan dan memiliki keragaman dimana merupakan gabungan produksi mesin dan tangan (Ibrahim, 2017). Desain yang bagus akan meningkatkan nilai tambah produk perhiasan. Tarigan (2009) dalam Wulandari et al. (2017) menyebutkan bahwa penguasaan keterampilan khusus, seperti desain produk perhiasan, merupakan suatu keunggulan komparatif.

- Industri perhiasan nasional merupakan industri yang mandiri karena tidak ada modal asing yang terlibat (Ibrahim, 2017).

- Industri perhiasan nasional mempunyai pasar global yang sudah matang, desain dan produk yang dihasilkan juga berkualitas baik dengan harga yang kompetitif. (Okezone, 2017).

- Industri perhiasan jatim telah mulai menjalankan mekanisasi dengan menggunakan mesin-mesin industri yang mampu menghasilkan perhiasan yang cukup bagus (Bappeda, 2015).

- Industri perhiasan jatim mempunyai sumber daya manusia dengan keterampilan yang cukup mumpuni (Endarwati, 2017).

- Industri perhiasan jatim mempunyai sebaran yang cukup baik dari segi skala (kecil, menengah maupun besar) dan dari segi geografis dimana tersebar di berbagai kota dan kabupaten (Ibrahim, 2017).

b. Kelemahan (weakness)

- Desain yang kurang bagus (Kompas, 2011). Industri perhiasan nasional kalah bersaing dengan Italia, Turki dan Hong Kong dalam desain produk perhiasan menggunakan berlian (Kominfo, 2011). Padahal seperti diuraikan sebelumnya, selera konsumen di China, salah satu pasar perhiasan terbesar dunia, telah bergeser dari konvensional emas menuju pada berlian.

- Tidak mampu memproduksi perhiasan berbahan batu mulia (Kompas, 2011).

- Jatim mempunyai potensi bahan baku perhiasan yang cukup namun belum tereksploitasi secara optimal (Jawatimuran, 2012).

- Kemampuan pengembangan desain dan penguasaan teknologi yang terbatas (Jawatimuran, 2012).

- Terus meningkatnya upah minimum regional (UMR) tenaga kerja yang tidak diimbangi dengan peningkatan produktivitas (Jawatimuran, 2012).

- Kurangnya penguasaan jaringan pasar domestik dan ekspor (Jawatimuran, 2012).

- Minimnya alokasi anggaran untuk promosi (Jawatimuran, 2012).

- Tidak ada fasilitas untuk standarisasi dan kurangnya fasilitas laboratorium untuk pengujian bahan baku yang diakui pasar internasional (Jawatimuran, 2012).

- Kurangnya perlindungan Hak Atas Kekayaan Intelektual atau HAKI atas desain produk-produk perhiasan (Jawatimuran, 2012).

c. Kesempatan (opportunity)

- Kelesuan industri perhiasan global merupakan peluang bagi industri perhiasan nasional untuk meningkatkan produktivitasnya serta berorientasi ekspor (Ibrahim, 2017).

- Terdapat potensi perkembangan pasar domestik industri perhiasan karena perbaikan kondisi perekonomian nasional tahun ini yang mendorong pertumbuhan kelas menengah dengan populasi penduduk yang cukup besar dan juga didukung dengan faktor kultur masyarakat (Okezone, 2017). 
- Ditemukannya sumber-sumber lokal tambang emas baru misalnya di Banyuwangi, Jember, Lumajang, Trenggalek dan Malang (Indonesiasatu, 2016).

- Negara-negara seperti India yang mempunyai kemampuan produksi yang besar dan desain yang terkenal unik, menghadapi berbagai masalah diantaranya "under-carated" yang merupakan masalah kepercayaan konsumen (World Gold Council, 2015).

d. Ancaman (threat)

- Ancaman peniruan desain-desain yang dihasilkan industri perhiasan nasional sehingga perlu dilindungi (Jajeli, 2016).

- Larangan ekspor secara hand-carry menghambat pertumbuhan ekspor. Sejak tahun 2015, ekspor perhiasan hanya boleh menggunakan kargo sehingga pengiriman barang menjadi kurang efisien karena timbulnya masalah waktu dan biaya dimana ada waktu tunggu pengiriman dan pembayaran asuransi (Radartegal, 2016).

- Ketergantungan terhadap impor bahan baku karena bahan baku lokal harganya cukup mahal dimana sangat dipengaruhi oleh harga gas industri. Apabila harganya turun, akan menimbulkan dampak positif bagi industri perhiasan karena harga baku di pengolahan emas akan turun (Radartegal, 2016).

- Meskipun Jatim cukup kaya dengan kandungan emas sebagai salah satu bahan baku industri perhiasan, penambangan emas disinyalir menimbulkan kerusakan lingkungan karena limbah arsenik trioksida yang ditimbulkan tidak mudah dikelola dan membutuhkan dana yang sangat besar untuk membekukannya.

Berikut ini disajikan analisis SWOT dalam perumusan strategi dengan memaksimalkan kekuatan (strength) dan kesempatan (opportunity) serta meminimalkan kelemahan (weakness) dan ancaman (threat).

a. Strategi S-O yaitu menggunakan kekuatan untuk memanfaatkan peluang

- Rencana pembangunan gemopolis, yang merupakan kawasan khusus untuk industri perhiasan dimana akan terdapat pabrik, kawasan perdagangan, fasilitas akomodasi dan sarana pendukung lainnya, seluas sekitar 100 hektar di dekat Bandara Internasional Juanda (Bappeda, 2015).

- Kementerian Perindustrian melalui Direktorat Jenderal Industri Kecil dan Menengah (Dirjen IKM) memberikan berbagai dukungan yaitu (Okezone, 2017):

- program e-smart IKM untuk mengakses pasar.

- restrukturisasi mesin dan peralatan IKM dalam rangka mendukung teknologi produksi perhiasan

- Supaya masalah "under-carated" yang terjadi pada industri perhiasan di India tidak terjadi di sini, Disperindag Jatim juga menyiapkan standar internasional yang merupakan usaha penjamin mutu atau hallmarking terhadap produk produk perhiasan yang dihasilkan (Beritadaerah, 2015).

b. Strategi S-T yaitu menggunakan kekuatan untuk mengatasi ancaman

- Dinas Perdagangan (Disperindag) Provinsi Jawa Timur memberikan pendampingan dalam pendaftaran hasil karya kerajinan perhiasan di Hak Atas Kekayaan Intelektual atau HAKI (Beritadaerah, 2015).

c. Strategi W-O yaitu meminimalkan kelemahan untuk memanfaatkan peluang

- Dirjen IKM memberikan pendampingan tenaga ahli desainer produk perhiasan un- 
tuk peningkatan kualitas dan desain (Okezone, 2017).

- Penyelenggaraan secara rutin di Surabaya berbagai pameran perhiasan dengan skala nasional maupun internasional seperti Surabaya Jewellery Fair (Beritadaerah, 2015) dan Internasional Jewellery Fair (Kompas, 2011). Kegiatan pameran harus menjadi wahana bagi industri perhiasan Jatim sebagai ajang promosi karena kegiatan tersebut juga mengundang peserta dari luar negeri untuk melihat potensi bahan baku dan hasil karya perajin Jatim yang belum terekspos (Kompas, 2011).

d. Strategi W-T yaitu meminimalkan kelemahan untuk menghindari ancaman

- Penerapan berbagai tarif dan pajak untuk masuknya hasil industri perhiasan asing guna melindungi industri emas Jatim dari perdagangan bebas (Kabarbisnis, 2015).

- Pemberian kemudahan untuk melakukan impor dalam pemenuhan bahan baku maupun mesin bekas. Bahan baku yang dipakai tidak umum dan banyak masuk pada kategori Lartas (Larangan Terbatas) sehingga tidak mudah diperoleh secara lokal (Endarwati, 2017).

- Pengurangan tarif bea masuk untuk intan (Endarwati, 2017).

- Melakukan evaluasi ijin dan kebijakan pertambangan emas sehingga tidak tumpang tindih dan menyebabkan berbagai masalah sosial, kerusakan lingkungan hingga korupsi yang merugikan masyarakat (Mongabay, 2016).

Apabila rincian di atas digambarkan pada matriks SWOT, maka akan nampak seperti pada Gambar 4 di bawah ini.

\section{Gambar 4: Matriks SWOT Industri Perhiasan Jatim}

\begin{tabular}{|c|c|c|}
\hline & $\begin{array}{l}\text { Strength }(\mathrm{S}) \\
\cdot \text { desain dinamis } \\
\cdot \text { pasar global yang matang } \\
\text { - harga kompetitif } \\
\text { - produksi sudah mekanis } \\
\text { sumber daya manusia yang } \\
\text { terampil } \\
\cdot \text { sebaran yang baik }\end{array}$ & $\begin{array}{l}\text { Weakness }(\mathrm{W}) \\
\text { - desain kurang inovatif } \\
\text { - belum optimalnya } \\
\text { eksploitasi bahan baku } \\
\text { - kemampuan penelitian dan } \\
\text { pengembangan terbatas } \\
\text { - terus meningkatnya upah } \\
\text { - minim anggaran promosi }\end{array}$ \\
\hline $\begin{array}{l}\text { Opportunities (O) } \\
\text { · kelesuan industri perhiasan } \\
\text { global } \\
\text { - potensi pasar } \\
\text { domestik } \\
\text { · adanya sumber } \\
\text { sumber tambang } \\
\text { emas baru } \\
\text { - negara kompetitor seperti } \\
\text { India } \\
\text { mempunyai masalah }\end{array}$ & $\begin{array}{l}\text { Strategi S-O } \\
\cdot \text { pembangunan Gemopolis } \\
\cdot \text { program e-smart IKM } \cdot \\
\text { restrukturisasi mesin } \\
\cdot \text { hallmarking }\end{array}$ & $\begin{array}{l}\text { Strategi W-O } \\
\text { - pendampingan desainer ahli } \\
\text { - penyelenggaraan secara rutin } \\
\text { pameran berskala } \\
\text { nasional maupun } \\
\text { internasional }\end{array}$ \\
\hline
\end{tabular}




\begin{tabular}{|c|c|c|}
\hline $\begin{array}{l}\text { Threaths }(\mathrm{T}) \\
\cdot \text { peniruan desain } \\
\cdot \text { larangan ekspor } \\
\text { hand-carry } \\
\cdot \text { ketergantungan } \\
\text { impor bahan baku } \\
\cdot \text { kerusakan } \\
\text { lingkungan karena } \\
\text { penambangan emas }\end{array}$ & $\begin{array}{l}\text { Strategi S-T } \\
\cdot \text { pendampingan HAKI }\end{array}$ & $\begin{array}{l}\text { Strategi W-T } \\
\text { - tarif dan pajak produk asing } \\
\text { · kemudahan importasi bahan } \\
\text { baku dan mesin } \\
\text { bekas } \\
\text { · pengurangan bea masuk } \\
\text { intan } \\
\text { · evaluasi ijin dan kebijakan } \\
\text { pertambangan emas }\end{array}$ \\
\hline
\end{tabular}

Sumber: data diolah

\section{Kesimpulan dan Saran}

Pengolahan data perdagangan dari BPS Jatim dan UN Comtrade telah memungkinkan untuk dilakukannya identifikasi tujuan-tujuan ekspor baru bagi produk-produk perhiasan Jatim. Dengan pengecualian terhadap Afrika, beberapa negara di benua lain yaitu Asia dan Oceania, Eropa dan Amerika merupakan pasar yang potensial bagi industri emas Jatim untuk meningkatkan nilai ekspornya saat ini serta menjadikan beberapa lainnya sebagai tujuan ekspor baru dalam mengembangkan pasar.

Untuk meningkatkan kapasitas industri perhiasan Jatim dalam GVC, sangat diperlukan peran aktif pemerintah dalam bentuk dukungan yang maksimal untuk penerapan berbagai strategi yang sudah dan akan dilakukan dimana telah berada pada jalur yang benar karena telah mengakomodasi berbagai faktor internal dan eksternal industri perhiasan Jatim. Berbagai strategi pemerintah untuk para pemangku kepentingan dalam mengembangkan industri perhiasan di Jatim telah difokuskan untuk dapat menghasilkan produk-produk perhiasan dengan nilai tambah yang tinggi melalui peningkatan kemampuan produksi dan desain, standarisasi proses dan hasil, perlindungan HAKI, promosi di dalam dan luar negeri, pemberlakuan tarif, pajak dan perijinan yang bersahabat serta pembangunan pusat industri emas (gemopolis) yang akan menjadikan Jatim sebagai pusat industri perhiasan dunia.

\section{Daftar Pustaka}

Backer, K. D. dan Miroudot, S. (2013). “Mapping Global Value Chains”. OECD Trade Policy Papers 159.

Badan Pusat Statistik Provinsi Jawa Timur. (2017). Statistik Ekspor Jawa Timur Tahun 2016. https://jatim.bps.go.id/4dm!n/pdf_publikasi/Statistik-Ekspor-ProvinsiJawaTimur-2016.pdf diunduh pada 26 Agustus 2017.

Badan Pusat Statistik Provinsi Jawa Timur. (2017). Berita Resmi Statistik No. 44/07/35/Th. XV, 17 Juli 2017. Perkembangan Ekspor dan Impor Jawa Timur Juni 2017. https://jatim.bps. go.id/4dm!n/brs_ind/brsInd 20170718094849.pdf diunduh pada 26 Agustus 2017.

Badan Pusat Statistik Provinsi Jawa Timur. (2016). Berita Resmi Statistik No. 49/06/35/Th. XIV, 15 Juli 2016. Perkembangan Ekspor dan Impor Jawa Timur Juni 2016. https://jatim.bps. go.id/4dm!n/brs_ind/brsInd 20160715105851.pdf diunduh pada 26 Agustus 2017.

Badan Pusat Statistik Provinsi Jawa Timur. (2015). Berita Resmi Statistik No. 48/07/35/Th. XIII, 15 Juli 2015. Perkembangan Ekspor dan Impor Jawa Timur Juni 2015. https://jatim.bps. go.id/4dm!n/brs_ind/brsInd 20150715130518.pdf diunduh pada 26 Agustus 2017.

Badan Pusat Statistik Provinsi Jawa Timur. (2014). Berita Resmi Statistik No. 52/08/35/Th. 
XII, 4 Agustus 2014. Perkembangan Ekspor dan Impor Jawa Timur Juni 2014. https:// jatim.bps.go.id/4dm!n/brs_ind/brsInd 20141201083923.pdf diunduh pada 26 Agustus 2017.

Bappeda Jawa Timur. (22 Oktober 2015). Pabrik Khusus Perhiasan Bakal Dibangun di Jawa Timur. $\quad$ http://bappeda.jatimprov.go.id/2015/10/22/pabrik-khusus-perhiasanbakaldibangun-di-jawa-timur/

Berita Daerah. (23 Oktober 2015). Jawa Timur Sediakan Lahan Perusahaan Perhiasan di Kawasan Bandara Internasional Juanda. http://beritadaerah.co.id/2015/10/23/jatimsediakan-lahan-perusahaan-perhiasandi-kawasan-bandara-internasional-juanda/

Cattaneo, O., et al. (2013). "Joining, Upgrading and Being Competitive in Global Value Chains: A Strategic Framework". International Trade Department, The World Bank Policy Research Working Paper 6406.

DaSilva-Glasgow, D. (2013). "Global Value Chains Analysis of the Gold Jewellery Industry: Upgrading Trajectories for Guyana". University of Guyana, Institute of Development Studies Working Paper 6/12.

Dewi, L. S. (2010). "Trend dan Daya Beli Masyarakat Indonesia Terhadap Perhiasan Logam Mulia". Vicidi 1.1, 53-65.

Endarwati, O. (27 februari 2017). Prospek Industri Perhiasan Masih Menjanjikan. Sindonews. https://ekbis.sindonews.com/read/1183822/34/prospek-industri-perhiasanmasihmenjanjikan-1488209366

Gulfnews. UAE Shoppers Go Easy On Gold Jewellery. http://gulfnews.com/business/gold-rate/ uae-shoppers-go-easy-on-gold-jewellery 1.1972439.

Ibrahim, A Malik. (27 Februari 2017). Menperin Dorong Peningkatan Produktivitas Emas Nasional. Antara Jatim. http://www.antarajatim.com/berita/193100/menperindorong-peningkatanproduktivitas-emas-nasional

Jajeli, R. (27 Oktober 2016). Ekspor Perhiasan di Jatim Tembus Rp 46 Triliun. Detik Finance. https://finance.detik.com/berita-ekonomi-bisnis/3331234/ekspor-perhiasan

Jawatimuran. (07 Juli 2012). Industri Perhiasan di Jawa Timur. Jawatimuran. https:// jawatimuran.net/2012/07/07/industri-perhiasan-di-jawa-timur/

Jawa Pos. (17 Mei 2017). Emas Jatim Gagal Berkilap. Jawa Pos. http://www.jawapos.com/ $\mathrm{read} / 2017 / 05 / 17 / 130781 /$ emas-jatim-gagal-berkilap

Kominfo Jatim. (14 Januari 2016). Jatim-Inggris Kerjasama Pendidikan. Kominfo Jatim. http:// kominfo.jatimprov.go.id/read/umum/jatim-inggris-kerjasama-pendidikan

Kominfo Jatim. (20 Agustus 2011). Industri Emas Jawa Timur Terbesar di Dunia. Kominfo Jatim. http://kominfo.jatimprov.go.id/read/umum/28121

Kompas. (19 Agustus 2011). Jawa Timur Pusat Industri Perhiasan Emas. Kompas Regional. http://regional.kompas.com/read/2011/08/19/17432634/Jawa.Timur.Pusat

Martudji, T. (19 Agustus 2011). Inilah Eksportir Emas Perhiasan Terbesar RI. Viva. http://www. viva.co.id/berita/bisnis/241872-inilah-eksportir-emas-perhiasan terbesar-ri. 
Media Indonesia. (28 April 2016). Penerapan Satu Data dari BPS Mulai 2017. Media Indonesia. http://mediaindonesia.com/news/read/42866/penerapan-satu-data-dari-bps-mulai 2017/2016-04-28

Nisak, Z. (2013). "Analisis Swot Untuk Menentukan Strategi Kompetitif”. Jurnal Ekbis 9.2.

Okezone. (1 Maret 2017). Menperin Sebut Prospek Industri Perhiasan Kinclong. Okezone. http:// economy.okezone.com/read/2017/03/01/320/1631198/menperin-sebutprospekindustri-perhiasan-kinclong

Radar Tegal. (2017). Ekspor Perhiasan Jawa Timur Moncer. http://radartegal.com/beritaekonomi/ekspor-perhiasan-jatim-moncer.11243.html

Serbanel, C. I. (2015). "Romania and Its Position on the Global Value Chain: An Introductive Analysis". 22nd International Economic Conference 2015.

United Nations International Trade Statistics Knowledgebase. Harmonized Commodity Description and Coding Systems (HS). https://unstats.un.org/unsd/tradekb/ Knowledgebase/50018/HarmonizedCommodity-Description-and-Coding-Systems-HS

United Nations International Trade Statistics Knowledgebase. What is UN Comtrade?. https:// unstats.un.org/unsd/tradekb/Knowledgebase/What-is-UN-Comtrade

Wulandari, I. G. A. A., et al. (2017). "Analisis Faktor-Faktor Yang Mempengaruhi Produksi Industri Perhiasan Logam Mulia Di Kota Denpasar". E-Jurnal Ekonomi dan Bisnis Universitas Udayana 6.1, 79-108.

http://www.kabarbisnis.com/read/2861842/pemprov-jatim-siapkan-lahan

http://indonesiasatu.co/detail/jawa-timur--selatan-emas--utara-minyak--dantengahnyalumpur

https://nasional.tempo.co/read/news/2014/07/04/206590474/aktivis-ban

http://www.republika.co.id/berita/ekonomi/makro/15/10/29/nwzh5g382-p

http://www.mongabay.co.id/2016/08/24/evaluasi-pertambangan-di-jawa-timurharusdilakukan-mengapa/ 